\title{
PENGARUH FAKTOR AKUNTANSI TERHADAP PREDIKSI PERINGKAT OBLIGASI
}

\author{
Henny \\ Fakultas Ekonomi Universitas Tarumanagara Jakarta \\ Email:henny_untar3@yahoo.com
}

\begin{abstract}
The purpose of this study was to reveal the accounting factors that affect the predictions bond ratings on non-financial companies in the Indonesia Stock Exchange. Data taken from non-financial companies listed on the Indonesia Stock Exchange. The selection of a sample of 20 companies using purposive sampling method. The method used to test the hypothesis is a stepwise method logistic regression analysis to examine of accounting factors namely the independent variable leverage, liquidity, profitability, productivity and growth on the dependent variable prediction bond ratings. Results from this study are variable profitability and productivity have an influence on the prediction of non-financial corporate bond ratings.
\end{abstract}

Key words: Rating obligation, Profitability and Poductivity

\begin{abstract}
Abstrak: Tujuan dari penelitian ini adalah untuk mengungkapkan faktor akuntansi yang mempengaruhi prediksi peringkat obligasi pada perusahaan non keuangan di Bursa Efek Indonesia. Data diambil dari perusahaan non keuangan yang terdaftar di Bursa Efek Indonesia. Pemilihan sampel sebanyak 20 perusahaan dengan menggunakan purposive sampling method. Metode penelitian yang digunakan untuk menguji hipotesis adalah logistic regression analysis metode stepwise untuk menguji faktor akuntansi yaitu variabel independen leverage, liquidity, profitability, productivity dan growth terhadap variabel dependen prediksi peringkat obligasi. Hasil dari penelitian ini adalah variabel profitability dan productivity memiliki pengaruh terhadap prediksi peringkat obligasi perusahaan non keuangan.
\end{abstract}

Kata kunci: Peringkat Obligasi, Profitability dan Productivity

\section{PENDAHULUAN}

Penelitian mengenai peringkat obligasi diperlukan karena masih terdapat perbedaan hasil penelitian menurut Andry (2005) bahwa faktor akuntansi yang berpengaruh terhadap prediksi peringkat obligasi adalah growth, dan hasil penelitian Almilia dan Devi (2007) menunjukkan bahwa faktor akuntansi dengan variabel likuiditas yaitu current ratio yang dapat mempengaruhi prediksi peringkat obligasi pada perusahaan manufaktur yang terdaftar di Bursa Efek Jakarta, sedangkan menurut hasil penelitian Magreta dan Nurmayanti (2009) menunjukkan bahwa faktor akuntansi yang berpengaruh terhadap prediksi peringkat obligasi adalah variabel profitabilitas dan produktivitas. Hasil penelitian Andry (2005) dan Almilia dan Devi (2007), serta Magreta dan Nurmayanti (2009) berbeda menurut hasil penelitian Amalia (2013) dan Septyawanti (2013) yaitu bahwa faktor akuntansi yang mempengaruhi prediksi peringkat obligasi adalah variabel 
leverage dan profitability. Perbedaan ini disebabkan perbedaan periode penelitian dan perbedaan sampel yang digunakan.

Obligasi adalah surat utang berupa sertifikat berisi kontrak utang antara penerbit obligasi dan investor obligasi tersebut. Informasi obligasi ini bisa didapatkan dari peringkat obligasi perusahaan. Peringkat obligasi ini diberikan oleh lembaga atau agen pemeringkat obligasi. Di Indonesia terdapat dua lembaga pemeringkat obligasi yaitu PT Pefindo (Pemeringkat Efek Indonesia) dan PT Kasnic Credit Rating Indonesia. Pada penelitian ini akan mengacu ke lembaga pemeringkat PT Pefindo karena PT Kasnic Credit Rating Indonesia pada tahun 2007 telah berubah nama menjadi Moody’s Indonesia yang kemudian pada tahun 2009 Moody's Corporation menutup cabangnya di Indonesia. Bank Indonesia sesuai dengan SE BI No.13/31/DPNP, 22 Desember 2011, mengakui tiga lembaga pemeringkat obligasi domestik yaitu PT Pefindo, PT ICRA Indonesia dan PT Fitch Ratings Indonesia. Oleh karena itu, data pemeringkat obligasi yang digunakan adalah data dari PT Pefindo, karena PT Pefindo (www.pefindo.com) merupakan lembaga pemeringkat independen yang didirikan lebih awal yaitu tahun 1993 dan masih terpercaya sampai sekarang.

Perbedaan periode penelitian dan sampel yang digunakan dalam penelitian yang melatarbelakangi penelitian inilah yang membuat perlu diteliti untuk mengetahui bukti empiris atas faktor akuntansi apa saja yang berpengaruh terhadap prediksi peringkat obligasi pada perusahaan non keuangan yang terdaftar di Bursa Efek Indonesia. Oleh karena itu periode penelitian yang dilakukan sebaiknya memiliki jumlah periode sama dan up to date. Untuk sampel yang akan digunakan dalam penelitian adalah perusahaan non keuangan, karena perusahaan non keuangan yang paling banyak dan dominan di Bursa Efek Indonesia.

Penelitian ini bertujuan untuk menguji apakah leverage, liquidity, profitability, productivity dan growth berpengaruh terhadap prediksi peringkat obligasi perusahaan non keuangan yang terdaftar di Bursa Efek Indonesia.

Hasil penelitian ini diharapkan dapat memberikan manfaat: (1) bagi investor obligasi yaitu mengenai informasi peringkat obligasi yang dapat diprediksikan dengan faktor akuntansi, sehingga investor mengetahui apakah investasi obligasi tersebut aman dan menguntungkan atau tidak bagi investor sebelum melakukan investasinya; (2) bagi akademisi, diharapkan dapat memberikan pandangan dan wawasan terhadap mata kuliah akuntansi keuangan dan analisa laporan keuangan mengenai prediksi peringkat obligasi; (3) bagi peneliti selanjutnya, diharapkan dapat digunakan sebagai sumber referensi dan informasi bagi penelitian yang berkaitan dengan prediksi peringkat obligasi.

\section{KAJIAN TEORI}

Teori Signal. Teori signal merupakan teori yang menjelaskan tentang adanya asimetri informasi antara pihak manajemen perusahaan dengan berbagai pihak yang berkepentingan terhadap informasi perusahaan. Asimetri informasi muncul karena adanya salah satu pihak yang mempunyai informasi lebih baik, misalnya seorang manajer yang mengetahui informasi mengenai prospek perusahaan yang lebih baik dibandingkan dengan investornya (Sari, 2007). Berkaitan dengan asimetri informasi, sangat sulit bagi investor dan kreditur untuk membedakan antara perusahaan yang berkualitas tinggi dan rendah. Teori signal menjelaskan bagaimana seharusnya perusahaan memberikan signal pada pengguna laporan keuangan. Informasi berupa pemberian peringkat obligasi yang 
dipublikasikan diharapkan dapat menjadi signal kondisi keuangan perusahaan dan menggambarkan kemungkinan yang terjadi terkait dengan utang yang dimiliki (Sari, 2007).

Obligasi. Menurut Subramanyam dan Wild (2008), perusahaan menginvestasikan aset dalam sekuritas investasi (disebut juga dengan marketable securuties). Tujuan dari sekuritas investasi ini adalah untuk menggunakan kas yang menganggur secara produktif. Sekuritas investasi dapat berupa utang atau ekuitas. Sekuritas utang (debt securities) adalah sekuritas yang mewakili hubungan sebagai kreditor terhadap pihak lain-misalnya obligasi perusahaan lain, obligasi pemerintah, surat utang, dan sekuritas pemerintah kota. Sekuritas ekuitas (equity securities) merupakan sekuritas yang mewakili kepemilikan pada entitas lain-contohnya adalah saham biasa dan saham preferen yang tidak dapat ditarik kembali. Perusahaan dapat menggolongkan sekuritas investasi menjadi aset lancar atau tidak lancar, tergantung dari jangka waktu investasi untuk sekuritas tersebut.

Menurut Kasmir (2014), Obligasi adalah surat utang perusahaan kepada pihak lain yang memiliki jangka waktu lebih dari satu tahun. Obligasi yang diterbitkan biasanya memiliki jenis yang berbeda. Menurut Bursa Efek Indonesia (www.idx.co.id), jenis-jenis obligasi yaitu: a) Dilihat dari sisi penerbit: Corporate Bond, Government Bond dan Municipal Bond; b) Dilihat dari sistem pembayaran bunga: Zero Coupon Bond, Coupon Bond, Fixed Coupon Bond, dan Floating Coupon Bond; c) Dilihat dari hak penukaran atau opsi: Convertible Bond, Exhangeable Bond, Callable Bond, dan Putable Bond; d) Dilihat dari segi jaminan atau kolateralnya: Secured Bond dan Unsecured.

Faktor Akuntansi. Menurut Sejati (2010), faktor akuntansi adalah salah satu faktor yang digunakan oleh agen pemeringkat obligasi berupa informasi akuntansi yang tersedia. Informasi ini diberikan dalam bentuk laporan keuangan perusahaan. Bagian dari laporan keuangan yang mendapatkan perhatian paling besar untuk digunakan dalam memprediksi peringkat obligasi adalah profitabilitas, leverage, likuiditas, size perusahaan, dan growth perusahaan serta produktivitas (Magreta dan Nurmayanti, 2009).

Leverage. Menurut Fahmi (2014:127) rasio leverage adalah mengukur seberapa besar perusahaan dibiayai dengan utang. Penggunaan utang yang terlalu tinggi akan membahayakan perusahaan karena perusahaan akan masuk dalam kategori extreme leverage (utang ekstrem) yaitu perusahaan terjebak dalam tingkat utang yang tinggi dan sulit untuk melepaskan beban utang tersebut. Karena itu sebaiknya perusahaan harus menyeimbangkan berupa utang yang layak diambil dan dari mana sumber-sumber yang dapat dipakai untuk membayar utang.

Rasio leverage yang akan digunakan dalam penelitian ini adalah Debt to Equity Ratio. Rumus Debt to Equity Ratio ini adalah Total Liabilities dibagi Total Equity (Fahmi, 2014:128). Hasil Debt to Equity Ratio ini akan baik kalau semakin rendah maka semakin baik karena aman bagi kreditor saat likuidasi.

Liquidity. Menurut Fahmi (2014:121) rasio liquidity adalah kemampuan suatu perusahaan memenuhi kewajiban jangka pendeknya secara tepat waktu. Contoh membayar listrik, telefon, air, gaji karyawan, gaji teknisi, gaji lembur dan sebagainya. Karena itu rasio likuiditas sering disebut dengan short term liquidity. Rasio likuiditas yang akan digunakan dalam penelitian ini adalah Current Ratio dengan rumus Current Assets dibagi Current Liabilities. Rasio lancar merupakan ukuran tingkat keamanan terhadap 
ketidakpastian dan kejutan, seperti pemogokan dan kerugian luar biasa, dapat membahayakan arus kas secara sementara dan tidak terduga.

Profitability. Menurut Fahmi (2014:135) rasio ini mengukur efektivitas manajemen secara keseluruhan yang ditujukan oleh besar kecilnya tingkat keuntungan yang diperoleh dalam hubungannya dengan penjualan maupun investasi. Semakin baik rasio profitabilitas maka semakin baik menggambarkan kemampuan tingginya perolehan keuntungan perusahaan.

Rasio profitabilitas yang akan digunakan adalah Return on Assets dengan rumus Total Net Income (atau Earning After Tax) dibagi dengan Total Assets. Rasio Return on Assets ini melihat sejauh mana investasi yang telah ditanamkan mampu memberikan pengembalian keuntungan sesuai dengan yang diharapkan. Dan investasi tersebut sebenarnya sama dengan asset perusahaan yang ditanamkan atau ditempatkan (Fahmi, 2014:137).

Productivity. Menurut Mahfudhoh dan Cahyonowati (2014), rasio produktivitas mengukur seberapa efektif perusahaan menggunakan sumber daya yang dimilikinya. Perusahaan yang rasio produktivitasnya tinggi memperlihatkan bahwa perusahaan mampu menghasilkan laba yang lebih tinggi dibandingkan dengan perusahaan yang rasio produktivitasnya lebih rendah. Rasio Productivity yang akan digunakan dalam penelitian ini adalah rasio Total Sales dibagi dengan Total Assets.

Growth. Menurut Ikhsan, Yahya dan Saidaturrahmi (2012), rasio growth merupakan rasio pertumbuhan perusahaan dimana pertumbuhan ini berdasarkan kesempatan bertumbuh perusahaan. Rasio growth ini diproksikan dengan Book to Market Ratio yaitu Book Value of Common Equity dibagi dengan Market Value of Common Equity.

Peringkat Obligasi. Peringkat obligasi adalah sebuah pernyataan tentang keadaan penerbit obligasi dan kemungkinan apa yang bisa dan akan dilakukan dengan obligasi yang dimiliki. Menurut Foster (1986) dalam Sari (2007), peringkat mencoba mengukur risiko kegagalan, yaitu peluang emiten atau peminjam akan mengalami kondisi tidak mampu memenuhi kewajiban keuangannya. Peringkat obligasi ini diharapkan dapat memberikan petunjuk bagi investor tentang kualitas investasi obligasi yang mereka minati.

Peringkat obligasi diberikan oleh lembaga atau agen pemeringkat obligasi. Lembaga atau agen pemeringkat obligasi adalah lembaga independen yang dapat memberikan informasi pemeringkatan skala risiko yang salah satunya adalah sekuritas obligasi yang memberikan informasi mengenai keamanan obligasi bagi investor. PT PEFINDO atau "PT Pemeringkat Efek Indonesia" (www.pefindo.com) didirikan di Jakarta pada tanggal 21 Desember 1993, melalui inisiatif Badan Pengawas Pasar Modal (BAPEPAM) dan Bank Indonesia. Pada tanggal 31 Agustus 1994, PEFINDO memperoleh izin usahanya dari BAPEPAM dengan Nomor. 39/PM-PI/1994 dan menjadi salah satu lembaga penunjang pasar modal di Indonesia. Tugas utama PEFINDO adalah untuk menyediakan suatu peringkat atas risiko kredit yang objektif, independen, serta dapat dipertanggungjawabkan atas penerbitan surat hutang yang diperdagangkan kepada masyarakat luas. Disamping melaksanakan kegiatannya dalam melakukan pemeringkatan surat hutang, PEFINDO juga menerbitkan dan mempublikasikan informasi kredit sehubungan dengan pasar perdagangan efek. Berikut ini tabel mengenai definisi peringkat obligasi perusahaan menurut PT Pefindo. 
Tabel 1. Definisi Peringkat Obligasi

\begin{tabular}{ll}
\hline Simbol & \multicolumn{1}{c}{ Arti } \\
\hline AAA & $\begin{array}{l}\text { Efek utang yang peringkatnya paling tinggi dan beresiko paling rendah yang } \\
\text { didukung oleh kemampuan obligor yang superior relatif dibanding entitas }\end{array}$ \\
& $\begin{array}{l}\text { Indonesia lainnya untuk memenuhi kewajiban jangka panjangnya sesuai dengan } \\
\text { perjanjian. }\end{array}$ \\
& $\begin{array}{l}\text { Efek utang yang memiliki kualitas kredit sedikit dibawah peringkat tertinggi, } \\
\text { didukung oleh kemampuan obligor yang sangat kuat untuk memenuhi kewajiban } \\
\text { financial jangka panjangnya sesuai dengan perjanjian, relatif dibanding dengan }\end{array}$ \\
& entitas Indonesia lainnya. Dan tidak mudah dipengaruhi oleh perubahan \\
& keadaan. \\
& $\begin{array}{l}\text { Efek utang yang beresiko investasi rendah dan memiliki kemampuan dukungan } \\
\text { obligor yang kuat dibanding entitas Indonesia lainnya untuk memenuhi }\end{array}$ \\
& kewajiban financialnya sesuai dengan perjanjian namun cukup peka terhadap \\
perubahan yang merugikan. & Efek utang yang beresiko investasi cukup rendah didukung oleh kemampuan \\
& obligor yang memadai, relatif dibanding entitas Indonesia lainnya untuk \\
& memenuhi kewajiban financialnya sesuai dengan perjanjian namun kemampuan \\
& tersebut dapat diperlemah oleh perubahan keadaan bisnis dan perekonomian \\
& yang merugikan.
\end{tabular}

BB Efek utang yang menunjukkan dukungan kemampuan obligor yang agak lemah relatif dibanding entitas Indonesia lainnya untuk memenuhi kewajiban financial jangka panjangnya sesuai dengan perjanjian serta peka terhadap keadaan bisnis dan perekonomian yang tidak menentu dan merugikan.

B Efek utang yang menunjukkan parameter perlindungan yang sangat lemah. Walaupun obligor masih memiliki kemampuan untuk memenuhi kewajiban financial jangka panjangnya, namun adanya perubahan keadaan bisnis dan perekonomian yang merugikan akan memperburuk kemampuan tersebut untuk memenuhi kewajiban financialnya.

CCC Efek utang yang tidak mampu lagi memenuhi kewajiban financialnya serta hanya bergantung kepada perbaikan keadaan eksternal.

D Efek utang yang macet atau emitennya sudah berhenti berusaha.

Sumber: PT Pefindo

Pengembangan Hipotesis. Berikut pengembangan hipotesis penelitian ini berdasarkan hasil penelitian terdahulu tersebut yang dilihat dari faktor akuntansi yaitu leverage, liquidity, profitability, productivity dan growth.

Pengaruh leverage terhadap prediksi peringkat obligasi. Menurut Septyawanti (2013) dalam penelitiannya menghasilkan bahwa variabel leverage berpengaruh terhadap peringkat obligasi, hasil penelitian ini konsisten dengan penelitian sebelumnya yang dilakukan oleh Raharja dan Sari (2008) dalam Septyawanti (2013). Leverage yang diproksikan melalui total utang dengan total modal memiliki pengaruh yang besar dalam prediksi peringkat obligasi. Hasil penelitian ini juga sejalan dengan penelitian Sari (2007), Amalia (2013) dan Murcia et al. (2014). Investor dirasa perlu menilai kelayakan jumlah utang yang dimiliki untuk mendanai operasional perusahaan. Perusahaan setidaknya memiliki proporsi jumlah utang yang lebih kecil dari jumlah modal yang dimiliki. Jumlah kewajiban yang lebih kecil juga dapat diartikan perusahaan mampu melunasi utang hanya 
dengan modal yang dimiliki. Pada sisi lain, penggunaan utang yang efektif untuk perluasan operasional perusahaan memberikan peluang perusahaan untuk memperoleh keuntungan yang lebih besar. Kepemilikan utang pada dasarnya diperbolehkan sejauh memberikan dampak positif bagi operasional perusahaan dan perusahaan mampu melaksanakan kewajibannya ketika jatuh tempo. Hasil penelitian ini tidak konsisten dengan hasil penelitian Mar Molinero, Appelaniz Gomez, and Serrano Cinca (1996), Alkhawaldeh (2013), Lestasi and Endri (2013), Magreta dan Nurmayanti (2009) dan Pandutama (2012) yang menunjukkan leverage tidak berpengaruh dalam memprediksi peringkat obligasi seluruh perusahaan yang terdaftar di PT Pefindo. Hal ini berarti bukan leverage yang dapat mempengaruhi prediksi peringkat obligasi.

Para peneliti memprediksi jika leverage cukup tinggi, maka hal tersebut menunjukkan tingginya penggunaan utang, sehingga hal tersebut dapat membuat perusahaan mengalami kesulitan keuangan dan memiliki resiko kebangkrutan cukup besar. Perusahaan dengan tingkat leverage yang rendah cenderung disukai para investor karena investor memiliki kepercayaan bahwa perusahaan akan mampu melunasi seluruh kewajibannya ketika utang tersebut telah jatuh tempo. Tingkat leverage yang rendah akan menunjukkan kuatnya kondisi keuangan perusahaan sehingga secara keuangan akan mempengaruhi prediksi peringkat obligasi. Oleh karena itu, hipotesisnya adalah :

$\mathrm{H}_{1}$ : Terdapat pengaruh leverage terhadap prediksi peringkat obligasi

Pengaruh liquidity terhadap prediksi peringkat obligasi. Hasil penelitian Almilia dan Devi (2007) serta Sari (2007) adalah likuiditas berpengaruh dalam memprediksi peringkat obligasi perusahaan. Hasil penelitian ini sesuai dengan penelitian yang dilakukan Burton et al. (2000) dalam Almilia dan Devi (2007) yang menunjukkan bahwa variabel likuiditas yang di ukur dengan rasio lancar (current ratio) mempunyai pengaruh terhadap prediksi peringkat obligasi, karena tingkat likuiditas yang tinggi akan menunjukkan kuatnya kondisi keuangan perusahaan sehingga secara financial akan mempengaruhi prediksi peringkat obligasi. Hal ini tidak konsisten dengan hasil penelitian Murcia et al. (2014), Magreta dan Nurmayanti (2009), Sejati (2010), Amalia (2013), Septyawanti (2013), Mahfudhoh dan Cahyonowati (2014) yang menyatakan bahwa liquidity tidak berpengaruh terhadap prediksi peringkat obligasi, hasil ini tidak sesuai dengan yang diharapkan, karena seharusnya liquidity melalui current ratio mempunyai hubungan yang positif dengan tingkat peringkat obligasi. Perbedaan hasil penelitian dapat disebabkan perbedaan sampel yang digunakan dan periode pengamatan, serta kesadaran para investor yang tidak hanya memperhatikan faktor finansial perusahaan, tetapi juga mencakup penilaian atas risiko industri dan risiko bisnis.

Para peneliti memprediksi tingkat likuiditas yang tinggi akan menunjukkan kuatnya kondisi keuangan perusahaan sehingga secara financial akan mempengaruhi prediksi peringkat obligasi. Berdasarkan analisis dan temuan di atas, maka hipotesisnya adalah:

$\mathrm{H}_{2}$ : Terdapat pengaruh liquidity terhadap prediksi peringkat obligasi

Pengaruh profitability terhadap prediksi peringkat obligasi. Menurut hasil penelitian Amalia (2013), variabel profitability yang diproksikan dengan Return on Assets berpengaruh positif terhadap peringkat obligasi di PT Pefindo. Semakin tinggi nilai Return on Assets, maka akan semakin tinggi pula perolehan peringkat obligasi. Penelitian ini memberikan hasil yang konsisten dengan beberapa penelitian sebelumnya yang dilakukan oleh Yuliana (2011), Pakarinti (2012), dan Arif (2012) dalam Amalia (2013), 
Mar Molinero, Apellaniz Gomez, and Serrano Cinca (1996), Al-khawaldeh (2013), Lestasi and Endri (2013), Murcia et al. (2014), Sari (2007), Magreta dan Nurmayanti (2009), serta Septyawanti (2013). Perbandingan laba bersih perusahaan dengan total assets perusahaan tepat digunakan untuk memprediksi peringkat obligasi. Hasil penelitian ini tidak konsisten dengan hasil penelitian Almilia dan Devi (2007), Sejati (2010), Pandutama (2012), Lestari dan Yasa (2014), serta Mahfudhoh dan Cahyonowati (2014) yang menyatakan bahwa profitability tidak berpengaruh terhadap peringkat obligasi. Perbedaan ini disebabkan karena adanya perbedaan pengukuran dari Return on Assets dan sampel penelitian sebagian besar memiliki laba yang rendah, sehingga investor tidak disarankan untuk memilih perusahaan penerbit obligasi yang mempunyai profitabilitas perusahaan yang baik.

Para peneliti memprediksi apabila laba perusahaan tinggi, maka akan memberikan peringkat yang naik pula sehingga variabel profitability ini dikatakan dapat mempengaruhi prediksi peringkat obligasi. Semakin tinggi tingkat profitabilitas perusahaan maka semakin rendah risiko ketidakmampuan membayar (default) dan semakin baik peringkat yang diberikan terhadap perusahaan tersebut. Berdasarkan analisis dan hasil penelitian di atas, maka hipotesisnya adalah:

$\mathrm{H}_{3}$ : Terdapat pengaruh profitability terhadap prediksi peringkat obligasi

Pengaruh productivity terhadap prediksi peringkat obligasi. Menurut Magreta dan Nurmayanti (2009) dalam penelitiannya, produktivitas berpengaruh dalam memprediksi peringkat seluruh perusahaan yang terdaftar di PT Pefindo. Hasil penelitian ini konsisten dengan hasil penelitian Sari (2007). Produktivitas berpengaruh terhadap prediksi peringkat obligasi menurut Horrigen (1966) dalam Magreta dan Nurmayanti (2009) disebabkan semakin tinggi rasio produktivitas maka semakin baik peringkat perusahaan tersebut. Penelitian tersebut hasilnya tidak konsisten dengan hasil dari Mahfudhoh dan Cahyonowati (2014) yang menyatakan bahwa productivity tidak berpengaruh terhadap prediksi peringkat obligasi. Hal ini berarti memberikan sinyal kepada investor, bahwa bukan productivity yang memberikan pengaruh terhadap peringkat obligasi.

Para peneliti memprediksi bahwa semakin tinggi rasio produktivitas maka semakin baik pula peringkat yang diberikan pada perusahaan tersebut. Berdasarkan analisis dan penelitian di atas, maka hipotesisnya adalah:

$\mathrm{H}_{4}$ : Terdapat pengaruh productivity terhadap prediksi peringkat obligasi

Pengaruh growth terhadap prediksi peringkat obligasi. Hasil penelitian Andry (2005) menyimpulkan bahwa growth ternyata mempunyai pengaruh terhadap prediksi peringkat obligasi. Ini sesuai dengan penelitian yang dilakukan oleh Pottier and Sommer (1999) dalam Andry (2005) yang mengenai industri asuransi di US, ditemukan bukti bahwa pertumbuhan (growth) bisnis yang kuat berhubungan positif dengan keputusan rating dan grade yang diberikan oleh pemeringkat obligasi. Hasil penelitian ini juga konsisten dengan hasil Murcia et al. (2014) dan Sejati (2010). Pada umumnya dengan pertumbuhan perusahaan yang baik akan memberikan peringkat obligasi yang investment grade. Hal ini tidak konsisten dengan hasil Ikhsan, Yahya dan Saidaturrahmi (2012), Pandutama (2012), Mahfudhoh dan Cahyonowati (2014) yang menyatakan bahwa growth tidak berpengaruh terhadap peringkat obligasi, karena pada periode pengamatan yang digunakana berbeda, dimana masa pengamatan peneliti situasi pesat dan kondisi negara sedang berada dalam 
kondisi yang labil sehingga menyebabkan kondisi keuangan dan pertumbuhan perusahaan menjadi labil pula.

Investor didalam memilih investasi terhadap obligasi akan melihat pengaruh growth atau pertumbuhan apabila pertumbuhan perusahaan dinilai baik maka perusahaan penerbit obligasi akan memiliki peringkat obligasi investment grade. Oleh karena itu investor disarankan untuk memilih perusahaan penerbit obligasi yang mempunyai pertumbuhan perusahaan yang baik. Para peneliti tersebut memprediksi bahwa perusahaan penerbit obligasi yang memiliki growth tinggi dari tahun ke tahun pada bisnisnya, memiliki kemungkinan lebih besar untuk memperoleh peringkat obligasi yang tinggi daripada perusahaan penerbit obligasi yang memiliki pertumbuhan yang rendah. Berdasarkan analisis dan hasil penelitian di atas, maka hipotesisnya adalah:

$\mathrm{H}_{5}$ : Terdapat pengaruh growth terhadap prediksi peringkat obligasi

\section{METODE}

Populasi dan Sampel. Populasi dalam penelitian ini adalah seluruh perusahaan non keuangan yang menerbitkan obligasi yaitu perusahaan yang terdaftar di Bursa Efek Indonesia (BEI) pada periode tahun 2010 s/d 2013. Penentuan sampel dilakukan dengan purposive sampling dengan menggunakan kriteria dalam pemilihan sampel. Prosedur pemilihan sampel dengan kriteria sebagai berikut: (1) Perusahaan non keuangan yang terdaftar di Bursa Efek Indonesia tahun 2010 s/d 2013; (2) Perusahaan non keuangan yang menerbitkan obligasi berturut-turut mulai tahun 2010 s/d 2013 di PT Pefindo.

Operasionalisasi Variabel Penelitian. Variabel Dependen (Y). Variabel dependen dalam penelitan ini adalah peringkat obligasi pada perusahaan non keuangan di Bursa Efek Indonesia. Variabel ini dilihat berdasarkan peringkat yang dikeluarkan oleh PT Pefindo yang secara umum terbagi menjadi dua yaitu investment grade (AAA, AA, A, $\mathrm{BBB})$ dan non investment grade (BB, B, CCC, D) yang diperkirakan akan dipengaruhi oleh faktor akuntansi berupa leverage, liquidity, profitability, productivity dan growth. Variabel dependen ini adalah variabel dummy dengan skala pengukurannya adalah skala nominal yaitu: jika peringkat obligasi yang investment grade diberi nilai 1 dan jika peringkat obligasi yang non investment grade diberi nilai 0.

Variabel Independen (X). Variabel independen dalam penelitian ini adalah (1) Leverage. Variabel Leverage diproksikan dengan Debt to Equity Ratio yaitu Total Libilities dibagi dengan Total Equity; (2) Liquidity. Liquidity diproksikan dengan Current Ratio yaitu Current Assets dibagi dengan Current Liabilities; (3) Profitability. Variabel Profitability diproksikan dengan Return on Assets yaitu Total Net Income dibagi dengan Total Assets; (4) Productivity. Productivity diproksikan dengan rasio Total Sales dibagi dengan Total Assets; (5) Growth. Growth diproksikan dengan Book to Market Ratio yaitu Book Value of Common Equity dibagi dengan Market Value of Common Equity.

Teknik Analisis Data. Teknik analisis data yang digunakan adalah regresi logistik dengan metode stepwise karena variabel dependennya merupakan data kualitatif yang menggunakan variabel dummy. Logistic regression yang dilakukan dengan metode stepwise bertujuan untuk mengetahui dan menganalisis variabel-variabel independen mana 
saja yang mampu membedakan antara variabel dependen kategori nilai 1 (satu) dan kategori nilai 0 (nol) (Ghozali, 2011:343).

Menurut Ghozali (2011:19) sebelum dilakukan regresi logistik dilakukan terlebih dahulu statistik deskriptif, yang harus dilakukan berikutnya adalah uji normalitas (Ghozali, 2011:29). Tetapi uji ini tidak dapat dilakukan karena untuk menguji hipotesis yang digunakan dalam penelitian ini adalah uji logistic regression dengan metode stepwise yang sebetulnya mirip dengan analisis diskriminan yaitu kita ingin menguji apakah probabilitas terjadinya variabel terikat dapat diprediksi dengan variabel bebasnya (Ghozali, 2011:333).

Tahapan dalam uji regresi logistik dengan metode stepwise ini adalah (Ghozali, 2011:346-348): (1) Menilai Model Fit (Overall Fit Model); (2) Uji Nagelkerke's $R$ Square; (3) Uji Hosmer and Lemeshow's Goodness of Fit Test; (4) Uji Ketepatan Prediksi.

Model regresi logistik yang digunakan adalah (Ghozali, 2011):

$$
\mathrm{Ln} \underset{1-\mathrm{P}(\mathrm{PO})}{1-\mathrm{PO})}=\alpha+\beta_{1} \mathrm{LEV}+\beta_{2} \mathrm{LIQ}+\beta_{3} \mathrm{PROF}+\beta_{4} \mathrm{PROD}+\beta_{5} \mathrm{GRO}+\mathrm{e}
$$

Keterangan:

PO : Peringkat Obligasi; LEV : Leverage; LIQ : Liquidity; PROF : Profitability; PROD : Productivity; GRO : Growth; $\alpha$ : Konstanta; $\beta_{1}, \beta_{2}, \beta_{3}, \beta_{4}, \beta_{5}$ : Koefisien regresi dari setiap varabel independent; e : Error

Jenis dan Sumber Data. Penelitian ini dilakukan dengan menggunakan data sekunder yang diperoleh dari data Indonesian Capital Market Directory (ICMD) tahun 2011 s/d 2014 dan database Bursa Efek Indonesia yaitu laporan keuangan perusahaan non keuangan selama periode 2010 s/d 2013.

\section{HASIL DAN PEMBAHASAN}

Populasi yang digunakan dalam penelitian ini adalah perusahaan non keuangan yang terdaftar di Bursa Efek Indonesia tahun 2010 s/d 2013. Pengambilan sampel dilakukan dengan metode purposive sampling. Jumlah perusahaan non keuangan yang terdaftar di Bursa Efek Indonesia selama tahun 2010 s/d 2013 secara berturut-turut adalah 422 perusahaan. Berdasarkan data yang diperoleh, perusahaan non keuangan yang memenuhi kriteria dalam penelitian ini adalah sebanyak 20 perusahaan. Dengan menggunakan penggabungan data selama 4 tahun, maka diperoleh sebanyak 20 x $4=80$ data pengamatan.

\begin{tabular}{|c|c|}
\hline Kriteria & Jumlah \\
\hline $\begin{array}{l}\text { Jumlah perusahaan non keuangan yang terdaftar di Bursa Efek Indonesia } \\
\text { tahun } 2010 \text { s/d } 2013\end{array}$ & 422 \\
\hline $\begin{array}{l}\text { Perusahaan non keuangan yang tidak menerbitkan obligasi berturut-turut } \\
\text { mulai tahun } 2010 \text { s/d } 2013 \text { di PT Pefindo }\end{array}$ & (402) \\
\hline $\begin{array}{l}\text { Jumlah perusahaan sampel yang menerbitkan obligasi berturut-turut } \\
\text { mulai tahun } 2010 \text { s/d } 2013 \text { di PT Pefindo }\end{array}$ & 20 \\
\hline
\end{tabular}

Tabel 2. Proses Seleksi Sampel Berdasarkan Kriteria 
Data peringkat obligasi perusahaan non keuangan pada tahun 2010-2013 diperoleh dari PT Pefindo. Data peringkat ini dibagi dalam dua golongan yaitu investment grade (AAA, AA, A, BBB) dan non investment grade (BB, B. CCC, D). Hal ini pun dapat dilihat pada Tabel berikut.

Tabel 3. Frekuensi Peringkat Obligasi

\begin{tabular}{llrrrr}
\hline & Frequency & Percent & Valid Percent & $\begin{array}{c}\text { Cumulative } \\
\text { Percent }\end{array}$ \\
\hline \multirow{3}{*}{ Valid } & Non Investment Grade & 14 & 17.5 & 17.5 & 17.5 \\
& Investment Grade & 66 & 82.5 & 82.5 & 100.0 \\
Total & 80 & 100.0 & 100.0 & \\
\hline
\end{tabular}

Tabel frekuensi peringkat obligasi di atas menunjukkan bahwa ada 66 (82.5\%) perusahaan yang memiliki peringkat obligasi kategori investment grade, sedangkan peringkat obligasi non investment grade ada 14 (17.5\%) perusahaan. Untuk peringkat obligasi kategori investment grade diberi nilai 1 dan non investment grade diberi nilai 0.

Statistik Deskriptif. Statistik deskriptif memberikan gambaran tentang data sampel yang digunakan dalam penelitian ini, sehingga dapat memperlihatkan nilai minimum, nilai maksimum, nilai rata-rata (mean) dan standar deviasi dari masing-masing variabel independen yaitu variabel leverage, liquidity, profitability, productivity dan growth, serta variabel dependen yaitu variabel peringkat obligasi. Berikut hasil uji statistik deskriptif penelitian ini:

Tabel 4. Hasil Uji Statistik Deskriptif

\begin{tabular}{lrrrrr}
\multicolumn{7}{c}{ Descriptive Statistics } \\
\hline PERINGKAT_OBLIG & $\mathrm{N}$ & Minimum & Maximum & \multicolumn{1}{c}{ Mean } & Std. Deviation \\
ASI & 80 & .00 & 1.00 & .8250 & .38236 \\
LEVERAGE & 80 & -7.54 & 5.67 & 1.2384 & 1.84658 \\
LIQUIDITY & 80 & .20 & 2.90 & 1.4775 & .69336 \\
PROFITABILITY & 80 & -.65 & .51 & .0274 & .15961 \\
PRODUCTIVITY & 80 & .08 & 2.00 & .7404 & .50405 \\
GROWTH & 80 & -9.58 & 5.39 & .4369 & 2.31891 \\
Valid N (listwise) & 80 & & & & \\
\hline
\end{tabular}

Hasil uji statistik deskriptif pada Tabel 4 menunjukkan bahwa Nilai N menunjukkan banyaknya data yang digunakan dalam penelitian ini yaitu 80 sampel. Variabel dependen yaitu peringkat obligasi selama tahun 2010 s/d 2013 dengan jumlah sampel sebanyak 80 sampel, mempunyai nilai rata-rata 0,8250 .

Variabel leverage yang diproksikan dengan Debt to Equity Ratio (DER) menunjukkan nilai minimum sebesar - 7,54 dan nilai maksimum sebesar 5,67 dengan nilai rata-rata sebesar 1,2384 dan standar deviasi sebesar 1,84658. Tingkat leverage terkecil sebesar -7,54 terjadi pada Arpeni Pratama Ocean Line Tbk pada tahun 2010. Tingkat leverage tertinggi sebesar 5,67 terjadi pada Adhi Karya (Persero) Tbk pada tahun 2012. Hasil ini menunjukkan dari 80 sampel data penelitian, Arpeni Pratama Ocean Line Tbk pada tahun 2010 yang memiliki leverage terendah.

Variabel liquidity yang diproksikan dengan Current Ratio (CR) menunjukkan nilai 
minimum sebesar 0,20 dan nilai maksimum sebesar 2,90 dengan nilai rata-rata sebesar 1,4775 dan standar deviasi sebesar 0,69336. Tingkat liquidity terkecil sebesar 0,20 terjadi pada Arpeni Pratama Ocean Line Tbk pada tahun 2010. Tingkat liquidity tertinggi sebesar 2,90 terjadi pada Bumi Serpong Damai Tbk pada tahun 2012. Hasil ini menunjukkan dari 80 sampel data penelitian, Bumi Serpong Damai Tbk pada tahun 2012 yang memiliki liquidity tertinggi.

Variabel profitability yang diproksikan dengan Return On Assets (ROA) menunjukkan nilai minimum sebesar $-0,65$ dan nilai maksimum sebesar 0,51 dengan nilai rata-rata sebesar 0,0274 dan standar deviasi sebesar 0,15961. Tingkat profitability terkecil sebesar -0,65 terjadi pada Berlian Laju Tanker Tbk pada tahun 2012. Tingkat profitability tertinggi sebesar 0,51 terjadi pada Matahari Putra Prima Tbk pada tahun 2010. Hasil ini menunjukkan dari 80 sampel data penelitian, Matahari Putra Prima Tbk pada tahun 2010 yang memiliki profitability tertinggi.

Variabel productivity yang diproksikan dengan Total Sales dibagi Total Assets menunjukkan nilai minimum sebesar 0,08 dan nilai maksimum sebesar 2,00 dengan nilai rata-rata sebesar 0,7404 dan standar deviasi sebesar 0,50405 . Tingkat productivity terkecil sebesar 0,08 terjadi pada Bakrieland Development Tbk pada tahun 2010. Tingkat productivity tertinggi sebesar 2,00 terjadi pada Japfa Comfeed Indonesia Tbk pada tahun 2010. Hasil ini menunjukkan dari 80 sampel data penelitian, Japfa Comfeed Indonesia Tbk pada tahun 2010 yang memiliki productivity tertinggi.

Variabel growth yang diproksikan dengan Book to Market Ratio (BMR) menunjukkan nilai minimum sebesar -9,58 dan nilai maksimum sebesar 5,39 dengan nilai rata-rata sebesar 0,4369 dan standar deviasi sebesar 2,31891. Tingkat growth terkecil sebesar -9,58 terjadi pada Arpeni Pratama Ocean Line Tbk pada tahun 2013. Tingkat growth tertinggi sebesar 5,39 terjadi pada Indah Kiat Pulp \& Paper Tbk pada tahun 2012. Hasil ini menunjukkan dari 80 sampel data penelitian, Indah Kiat Pulp \& Paper Tbk pada tahun 2012 yang memiliki growth tertinggi.

Pengujian Regresi Logistik Metode Stepwise. Pengujian regresi logistik dengan metode stepwise dalam penelitian ini bertujuan untuk mengetahui variabel-variabel mana saja yang mampu membedakan antara perusahaan peringkat obligasi kriteria investment grade dan non investment grade. Tahap untuk menilai model regresi logistik metode stepwise antara lain:

a. Menilai Model Fit (Overall Fit Model). Menilai model fit yang digunakan berdasarkan pada fungsi likelihood. Likelihood L dari model adalah probabilitas bahwa model yang dihipotesakan menggambarkan data input. Untuk menguji hipotesis nol dan alternatif, L ditransformasikan menjadi -2LogL. Menilai angka -2LogL pada awal (blok number $=0$ ) dan angka $-2 \operatorname{LogL}$ pada blok number $=1$, jika terjadi penurunan angka -2LogL maka menunjukkan model regresi yang baik. Berikut adalah hasil penilaian nilai -2 Likelihood (-2LogL) pada Tabel 5.

Berdasarkan hasil penilaian yang telah dilakukan untuk menilai model fit maka dapat dilihat pada Tabel 5 hasil penilaian -2 Likelihood yang terjadi penurunan dari Block Number $=0$ sebesar 74,196 menjadi 52,415 pada Block Number $=1$.

Penurunan yang terjadi sebesar 21,781 dari hasil ini dapat diketahui bahwa model regresi menjadi lebih baik saat variabel independen dimasukkan ke dalam model regresi dan menghasilkan data yang cocok pada penelitian ini. Hal ini dapat disimpulkan bahwa model regresi yang dihipotesiskan fit dengan data. 
Tabel 5. Hasil Penilaian -2 Likelihood Test

\begin{tabular}{cc}
\hline Step & -2 Likelihood \\
\hline Block Number $=0$ & 74,196 \\
Block Number $=1$ & 52,415 \\
\hline
\end{tabular}

b. Uji Nagelkerke's $R$ Square. Nagelkerke's $R$ Square merupakan modifikasi dari koefisien Cox dan Snell untuk memastikan bahwa nilainya bervariasi dari 0 (nol) sampai 1 (satu). Hal ini dilakukan dengan cara membagi nilai Cox dan Snell's $\mathrm{R}^{2}$ dengan nilai maksimumnya. Nilai Nagelkerke's dapat diinterpretasikan seperti nilai $\mathrm{R}^{2}$ pada multiple regression. Nilai $\mathrm{R}$ Square menjelaskan besarnya variasi dari variabel dependen yang dapat dijelaskan oleh variabel independen dan sisanya yang tidak dapat dijelaskan merupakan bagian variasi dari variabel lain yang tidak dimasukkan ke dalam model. Berikut adalah hasil uji Nagelkerke's $R$ Square penelitian ini pada Tabel 6.

Tabel 6. Hasil Uji Nagelkerke’s R Square

\begin{tabular}{cccc}
\hline Step & -2 Log Likelihood & Cox \& Snell R Square & Nagelkerke R Square \\
\hline 2 & $52,415^{\mathrm{b}}$ & 0,238 & 0,398 \\
\hline
\end{tabular}

Berdasarkan hasil uji Nagelkerke's $R$ Square pada Tabel 6 di atas sebesar 0,398. Hal ini berarti 39,8\% variasi dari variabel dependen yaitu peringkat obligasi dijelaskan oleh variabel independen yang ada yaitu Profitability dan Productivity, sedangkan 60,2\% dijelaskan oleh variabel lainnya yang tidak diteliti dalam penelitian ini.

c. Uji Hosmer and Lemeshow's Goodness of Fit Test. Hosmer and Lemeshow's Goodness of Fit Test menguji hipotesis nol bahwa data empiris cocok atau sesuai dengan model (tidak ada perbedaan antara model dengan data sehingga model dapat dikatakan fit). Jika nilai Hosmer and Lemeshow's Goodness of Fit Test statistics sama dengan atau kurang dari 0.05, maka hipotesis nol ditolak yang berarti ada perbedaan signifikan antara model dengan nilai observasinya sehingga Goodness Fit model tidak baik karena model tidak dapat memprediksi nilai observasinya. Jika nilai Hosmer and Lemeshow's Goodness of Fit Test statistics lebih besar dari 0.05, maka hipotesis nol tidak dapat ditolak dan berarti model mampu memprediksi nilai observasinya atau dapat dikatakan model dapat diterima karena cocok dengan data observasinya.

Tabel 7. Hasil Uji Hosmer and Lemeshow's Goodness of Fit Test

\begin{tabular}{cccc}
\hline Step & Chi-square & Df & Sig. \\
\hline 2 & 2,197 & 8 & 0,974 \\
\hline
\end{tabular}

Berdasarkan hasil uji Hosmer and Lemeshow's Goodness of Fit Test dalam Tabel 7 menunjukkan hasil Chi-square 2,197 dan nilai signifikan sebesar 0,974. Besar nilai signifikan yang terdapat dalam hasil uji ini menunjukkan bahwa signifikan lebih dari 0,05, maka dapat diartikan bahwa model regresi dapat memprediksikan nilai observasinya dan 
terdapat kecocokan model regresi dengan data empiris yang ada sehingga data ini dapat digunakan untuk dianalisis lebih lanjut.

d. Uji Ketepatan Prediksi. Untuk menilai uji ketepatan prediksi dengan regresi logistik metode stepwise adalah melihat class plot (tabel klasifikasi). Tabel klasifikasi digunakan untuk menghitung nilai estimasi yang benar dan salah. Pada kolom menunjukkan dua nilai prediksi dari variabel dependen. Untuk penelitian ini invesment grade bernilai 1 (satu) dan non investment grade bernilai 0 (nol), sedangkan pada baris menunjukkan nilai observasi sesungguhnya dari variabel dependen. Pada model yang sempurna, semua kasus akan berada pada diagonal dengan tingkat ketepatan peramalan 100\%.

Tabel 8. Hasil Uji Ketepatan Prediksi

Classification Table ${ }^{\mathrm{a}}$

\begin{tabular}{|c|c|c|c|c|c|}
\hline \multirow{3}{*}{\multicolumn{2}{|c|}{ Observed }} & & \multicolumn{3}{|c|}{ Predicted } \\
\hline & & & \multicolumn{2}{|c|}{ PERINGKAT_OBLIGASI } & \multirow{2}{*}{$\begin{array}{l}\text { Percentag } \\
\text { e Correct }\end{array}$} \\
\hline & & & $\begin{array}{c}\text { Non } \\
\text { Investment } \\
\text { Grade }\end{array}$ & $\begin{array}{l}\text { Investment } \\
\text { Grade }\end{array}$ & \\
\hline \multirow{2}{*}{ Step 2} & \multirow{2}{*}{$\begin{array}{l}\text { PERINGKAT } \\
\text { OBLIGASI }\end{array}$} & $\begin{array}{l}\text { Non Investment } \\
\text { Grade }\end{array}$ & 5 & 9 & 35.7 \\
\hline & & Investment Grade & 1 & 65 & 98.5 \\
\hline
\end{tabular}

a. The cut value is .500

Berdasarkan hasil uji ketepatan prediksi maka dapat terlihat dalam Tabel 8 bahwa dari 14 obligasi berkategori non investment grade yang dianalisis selama periode 2010-2013, terdapat 5 yang diprediksikan sebagai obligasi non investment grade dan terdapat 9 yang diprediksikan sebagai obligasi investment grade serta memiliki ketepatan prediksi sebesar 35,7\%. Untuk 66 obligasi investment grade yang dianalisis selama periode 2010-2013, terdapat 1 yang diprediksikan sebagai obligasi non investmet grade dan terdapat 65 yang diprediksikan sebagai obligasi investment grade serta memiliki ketepatan prediksi sebesar 98,5\%. Secara keseluruhan persentase ketepatan prediksi dapat terlihat sebesar 87,5\%, maka dapat disimpulkan bahwa model regresi logistik dengan metode stepwise masih cukup baik dalam melakukan prediksi.

Analisis regresi logistik dengan metode stepwise menghasilkan model regresi yang paling baik, karena dapat terlihat variabel independen apa saja yang dapat mempengaruhi variabel dependen. Untuk melihat sejauh mana pengaruhnya secara keseluruhan variabel independen berpengaruh terhadap variabel dependennya maka dapat terlihat dalam Tabel 9 yaitu hasil uji overall test.

Hasil uji overall test pada Step 2 dalam Tabel 9 menunjukkan bahwa seluruh variabel independen (X) yaitu variabel profitability dan productivity berpengaruh signifikan terhadap variabel dependennya (Y) yaitu peringkat obligasi, karena omnibus test of model coefficients di atas terlihat bahwa tingkat signifikansinya 0,00 yang berarti kurang dari 0,05.

Hasil uji overall test pada Tabel 9 didukung dengan hasil uji partial test pada Tabel 10 yaitu terdapat dua variabel independen yaitu variabel profitability dengan tingkat 
signifikansi 0,019 dan productivity dengan tingkat signifikansi 0,048 yang memiliki pengaruh positif terhadap variabel dependen peringkat obligasi.

Tabel 9. Hasil Uji Overall Test

\begin{tabular}{|c|c|c|c|c|}
\hline & & Chi-square & $\mathrm{df}$ & Sig. \\
\hline \multirow{3}{*}{ Step 1} & Step & 14.659 & 1 & .000 \\
\hline & Block & 14.659 & 1 & .000 \\
\hline & Model & 14.659 & 1 & .000 \\
\hline \multirow{3}{*}{ Step 2} & Step & 7.122 & 1 & .008 \\
\hline & Block & 21.781 & 2 & .000 \\
\hline & Model & 21.781 & 2 & .000 \\
\hline
\end{tabular}

Tabel 10. Hasil Uji Partial Test

Variables in the Equation

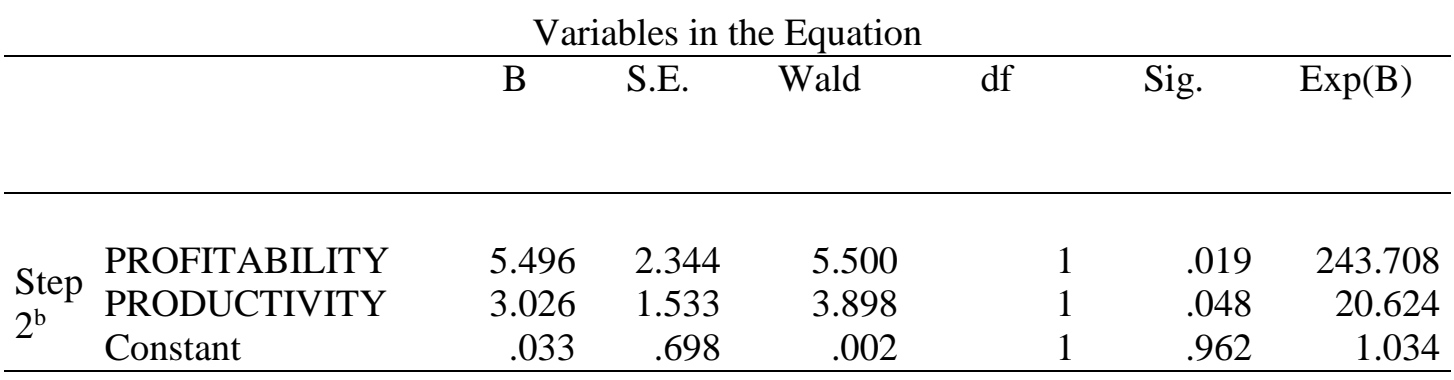

Berdasarkan hasil uji partial test di atas, maka dapat dinyatakan regresi logistik dengan metode stepwise dalam penelitian ini sebagai berikut:

$$
\mathrm{Y}=0,033+5,496(\mathrm{PROF})+3.026(\mathrm{PROD})+\mathrm{e}
$$

Keterangan: $\mathrm{Y}=$ Peringkat Obligasi; $\mathrm{PROF}=$ Profitability; $\mathrm{PROD}=$ Productivity $\mathrm{e}=$ Error

Interpretasi atas hasil persamaan regresi di atas menunjukkan bahwa semakin tinggi nilai Profitability dan Productivity perusahaan non keuangan yang terdaftar di Bursa Efek Indonesia, maka probabilitas perusahaan non keuangan tersebut mempunyai peringkat obligasi di atas rata-rata juga semakin menuju kategori peringkat obligasi investment grade.

Hasil pengujian hipotesis pertama menunjukkan bahwa variabel leverage yang diproksikan dengan Debt to Equity Ratio tidak muncul dalam persamaan regresi. Hasil ini menunjukkan bahwa variabel tersebut secara statistik tidak berpengaruh terhadap prediksi peringkat obligasi. Hasil penelitian ini tidak mendukung hasil penelitian Septyawanti (2013), Raharja dan Sari (2008) dalam Septyawanti (2013), Sari (2007), Amalia (2013) dan Murcia et al. (2014) yaitu investor dirasa perlu menilai kelayakan jumlah utang yang dimiliki untuk mendanai operasional perusahaan. Perusahaan setidaknya memiliki proporsi jumlah utang yang lebih kecil dari jumlah modal yang dimiliki.

Jumlah kewajiban yang lebih kecil juga dapat diartikan perusahaan mampu melunasi utang hanya dengan modal yang dimiliki. Hasil penelitian ini konsisten dengan hasil penelitian Mar Molinero, Appelaniz Gomez, and Serrano Cinca (1996), Al-khawaldeh (2013), Lestasi and Endri (2013), Magreta dan Nurmayanti (2009) dan Pandutama (2012) 
yang menunjukkan leverage tidak berpengaruh dalam memprediksi peringkat obligasi seluruh perusahaan yang terdaftar di PT Pefindo. Hal ini berarti bukan leverage yang dapat mempengaruhi prediksi peringkat obligasi, tetapi ada faktor lain yang mempengaruhi prediksi peringkat obligasi.

Tabel 11. Hasil Hipotesis

\begin{tabular}{cllcc}
\hline No & \multicolumn{1}{c}{ Hipotesis } & \multicolumn{2}{c}{ Nilai Uji } & \multirow{2}{*}{ Keterangan } \\
\cline { 3 - 4 } & B & Sig & \\
\hline 1 & $\begin{array}{l}\text { Terdapat pengaruh leverage terhadap prediksi } \\
\text { peringkat obligasi }\end{array}$ & - & - & - \\
2 & $\begin{array}{l}\text { Terdapat pengaruh liquidity terhadap prediksi } \\
\text { peringkat obligasi }\end{array}$ & - & - & - \\
3 & $\begin{array}{l}\text { Terdapat pengaruh profitability terhadap } \\
\text { prediksi peringkat obligasi }\end{array}$ & 5,496 & 0,019 & Diterima \\
4 & $\begin{array}{l}\text { Terdapat pengaruh productivity terhadap } \\
\text { prediksi peringkat obligasi }\end{array}$ & 3,026 & 0,048 Diterima \\
5 & $\begin{array}{l}\text { Terdapat pengaruh growth terhadap prediksi } \\
\text { peringkat obligasi }\end{array}$ & - & - & - \\
\hline
\end{tabular}

Hasil pengujian hipotesis kedua menunjukkan bahwa variabel liquidity yang diproksikan dengan Current Ratio tidak muncul dalam persamaan regresi. Hasil ini menunjukkan variabel tersebut secara statistik tidak berpengaruh terhadap prediksi peringkat obligasi. Hasil penelitian ini tidak mendukung hasil penelitian Almilia dan Devi (2007), Sari (2007), Burton et al. (2000) dalam Almilia dan Devi (2007) yang menunjukkan bahwa variabel likuiditas yang di ukur dengan rasio lancar (current ratio) mempunyai pengaruh terhadap prediksi peringkat obligasi, karena tingkat likuiditas yang tinggi akan menunjukkan kuatnya kondisi keuangan perusahaan sehingga secara financial akan mempengaruhi prediksi peringkat obligasi. Hasil penelitian ini konsisten dengan hasil penelitian Murcia et al. (2014), Magreta dan Nurmayanti (2009), Sejati (2010), Amalia (2013), Septyawanti (2013), Mahfudhoh dan Cahyonowati (2014) yang menyatakan bahwa liquidity tidak berpengaruh terhadap prediksi peringkat obligasi, hasil ini tidak sesuai dengan yang diharapkan, karena seharusnya liquidity melalui current ratio mempunyai hubungan yang positif dengan tingkat peringkat obligasi. Perbedaan hasil penelitian dapat disebabkan perbedaan sampel yang digunakan dan periode pengamatan, serta kesadaran para investor yang tidak hanya memperhatikan faktor finansial perusahaan, tetapi juga mencakup penilaian atas risiko industri dan risiko bisnis.

Hasil pengujian hipotesis ketiga menunjukkan bahwa variabel profitability yang diproksikan dengan Return On Assets menunjukkan koefisien regresi positif sebesar 5,496 dengan tingkat signifikansi 0,019 lebih kecil dari 0,05, maka variabel profitability memiliki pengaruh positif yang signifikan terhadap prediksi peringkat obligasi. Hasil ini mendukung hasil penelitian Amalia (2013), variabel profitability yang diproksikan dengan Return on Assets berpengaruh positif terhadap peringkat obligasi di PT Pefindo. Semakin tinggi nilai Return on Assets, maka akan semakin tinggi pula perolehan peringkat obligasi. Penelitian ini memberikan hasil yang konsisten dengan beberapa penelitian sebelumnya yang dilakukan oleh Yuliana (2011), Pakarinti (2012), dan Arif (2012) dalam Amalia (2013), Mar Molinero, Apellaniz Gomez, and Serrano Cinca (1996), Al-khawaldeh (2013), Lestasi and Endri (2013), Murcia et al. (2014), Sari (2007), Magreta dan Nurmayanti (2009), serta Septyawanti (2013). Perbandingan laba bersih perusahaan 
dengan total assets perusahaan tepat digunakan untuk memprediksi peringkat obligasi. Hasil penelitian ini memberikan interpretasi apabila laba perusahaan tinggi, maka akan memberikan peringkat yang naik pula sehingga variabel profitability ini dikatakan dapat mempengaruhi prediksi peringkat obligasi. Makin tinggi tingkat profitabilitas perusahaan maka semakin rendah risiko ketidakmampuan membayar (default) dan semakin baik peringkat obligasi yang diberikan terhadap perusahaan tersebut.

Hasil pengujian hipotesis keempat menunjukkan bahwa variabel productivity yang diproksikan dengan rasio Total Sales dibagi dengan Total Assets menunjukkan koefisien regresi positif sebesar 3,026 dengan tingkat signifikansi 0,048 lebih kecil dari 0,05, maka variabel productivity memiliki pengaruh positif yang signifikan terhadap prediksi peringkat obligasi. Hasil ini mendukung hasil penelitian Magreta dan Nurmayanti (2009) dalam penelitiannya, produktivitas berpengaruh dalam memprediksi peringkat seluruh perusahaan yang terdaftar di PT Pefindo. Hasil penelitian ini konsisten dengan hasil penelitian Sari (2007). Produktivitas berpengaruh terhadap prediksi peringkat obligasi menurut Horrigen (1966) dalam Magreta dan Nurmayanti (2009) disebabkan semakin tinggi rasio produktivitas maka semakin baik peringkat perusahaan tersebut. Hasil penelitian ini memberikan interpretasi semakin tinggi rasio produktivitas maka semakin tinggi pula total sales perusahaan non keuangan atas total assets yang dimiliki sehingga semakin baik peringkat obligasi yang diberikan pada perusahaan tersebut.

Hasil pengujian hipotesis kelima menunjukkan bahwa variabel growth yang diproksikan dengan Book to Market Ratio tidak muncul dalam persamaan regresi. Hasil ini menunjukkan bahwa variabel tersebut secara statistik tidak berpengaruh terhadap prediksi peringkat obligasi. Hasil ini tidak mendukung hasil penelitian Andry (2005), Pottier and Sommer (1999) dalam Andry (2005), Murcia et al. (2014) dan Sejati (2010) menyimpulkan bahwa growth ternyata mempunyai pengaruh terhadap prediksi peringkat obligasi. Hasil penelitian ini mendukung hasil penelitian Ikhsan, Yahya dan Saidaturrahmi (2012), Pandutama (2012), Mahfudhoh dan Cahyonowati (2014) yang menyatakan bahwa growth tidak berpengaruh terhadap peringkat obligasi, karena pada periode pengamatan yang digunakan berbeda, dimana masa pengamatan peneliti dan kondisi negara sedang berada dalam kondisi yang labil sehingga menyebabkan kondisi keuangan dan pertumbuhan perusahaan menjadi labil pula. Investor di dalam memilih investasi terhadap obligasi tidak akan melihat pengaruh growth atau pertumbuhan walaupun pertumbuhan perusahaan dinilai baik.

\section{PENUTUP}

Simpulan. Penelitian ini merupakan penelitian yang memberikan jawaban faktor akuntansi apa saja yang berpengaruh terhadap prediksi peringkat obligasi. Faktor akuntansi yang mempengaruhi prediksi peringkat obligasi ada 2 (dua) dalam variabel independen. Dari lima variabel independen yang diteliti yaitu leverage, liquidity, profitability, productivity, dan growth. Variabel profitability dan productivity yang berpengaruh positif terhadap prediksi peringkat obligasi pada perusahaan non keuangan yang terdaftar di Bursa Efek Indonesia. Hal ini berarti perusahaan non keuangan yang memiliki peringkat obligasi investment grade tidak berdasarkan variabel leverage, liquidity, dan growth, karena ketiga variabel ini tidak muncul dalam persamaan regresi logistik dengan metode stepwise. Hasil ini menunjukkan bahwa ketiga variabel tersebut secara statistik tidak berpengaruh terhadap prediksi peringkat obligasi. 
Penelitian ini memiliki keterbatasan. Pertama, penelitian ini tidak memasukkan seluruh perusahaan yang terdaftar di Bursa Efek Indonesia. Kedua, penelitian ini hanya menggunakan faktor akuntansi dalam menguji berpengaruhnya terhadap prediksi peringkat obligasi.

Saran. Atas dasar keterbatasan penelitian di atas, maka untuk penelitian selanjutnya disarankan: Pertama, memasukkan seluruh perusahaan yang terdaftar di Bursa Efek Indonesia sehingga hasil penelitiannya dapat digeneralisasi dan lebih komprehensif. Kedua, penelitian berikutnya dapat menambahkan faktor non akuntansi seperti sinking fund, risk, umur obligasi, kebijakan pemerintah, tingkat keamanan politik dan reputasi auditor, sehingga hasil penelitian lebih tepat.

\section{DAFTAR RUJUKAN}

Al-khawaldeh, Abdullah Ash-shu'ayree. (2013) "Determinants and Impacts of Internal Credit Rating”. Sciedu Press: International Journal of Financial Reserach. 4 (1): 120-131.

Almilia, Luciana Spica dan Vieka Devi. (2007) "Faktor-faktor yang Mempengaruhi Prediksi Peringkat Obligasi Pada Perusahaan Manufaktur yang Terdaftar di Bursa Efek Jakarta”. Proceeding Seminar Nasional Manajemen SMART. Universitas Kristen Maranatha Bandung. November. Hal.1-22.

Amalia, Ninik. (2013) "Pemeringkatan Obligasi PT Pefindo: Berdasarkan Informasi Keuangan”. Accounting Analysis Journal. Universitas Negeri Semarang. 2 (2):139147.

Andry, Wydia. (2005) ”Analisis Faktor-faktor yang Mempengaruhi Prediksi Peringkat Obligasi”. Buletin Ekonomi dan Perbankan. September. Hal.231-250.

Bursa Efek Indonesia, Indonesian Capital Market Directory 2011-2014. Jakarta: Bursa Efek Indonesia.

Fahmi, Irham. (2014) Analisis Laporan Keuangan. Bandung: Penerbit Alfabeta.

Ghozali, Imam. (2011) Aplikasi Analisis Multivariate dengan IBM SPSS 19. Edisi 5. Semarang: Universitas Diponogoro.

Ikhsan, Adhisyahfitri Evalina, M. Nur Yahya dan Saidaturrahmi. (2012) Peringkat ”Obligasi dan Faktor yang Mempengaruhinya”. Pekbis Jurnal. Juli. 4 (2): 115-123.

Kasmir. (2014) Analisis Laporan Keuangan. Jakarta: PT RajaGrafindo Persada.

Lestari, Kadek Yuni dan Gerianta Wirawan Yasa. (2014) ”Pengaruh Penerapan Corporate Governance dan Profitabilitas Terhadap Peringkat Obligasi”. E-Jurnal Akuntansi Universitas Udayana. 8 (1): 227-249.

Lestasi, Setyani Dwi dan Endri. (2013) "The Effects of Financial Performance to Corporate Sukuk Ratings in Indonesia”. Chiang Mai-Bangkok: The $2^{\text {nd }}$ IBSM International Conference on Business and Management.

Magreta dan Poppy Nurmayanti. (2009) "Faktor-faktor yang Mempengaruhi Prediksi Peringkat Obligasi Ditinjau dari Faktor Akuntansi dan Non Akuntansi”. Jurnal Bisnis dan Akuntansi. 11 (3): 143-154.

Mahfudhoh, Ratih Umroh dan Nur Cahyonowati. (2014) "Analisis Faktor-faktor yang Mempengaruhi Peringkat Obligasi”. Diponegoro Journal of Accounting. 1 (1): 1-13. 
Mar Molinero, C. P. Apellaniz and C. Serrano Cinca. (1996) "A Multivariate Analysis of Spanish Bond Ratings”. Omega: International Journal of Management Science. 24 (4): 451-462.

Murcia, at all. (2014) “The Determinants of Credit Rating: Brazilian Evidence”. Rio de Jeneiro: Brazilian Administration Review. On-line version ISSN 1807-7692. 11 (2).

Pandutama, Arvian. (2012) "Faktor-faktor yang Mempengaruhi Prediksi Peringkat Obligasi Pada Perusahaan Manufaktur di BEI”. Jurnal Ilmiah Mahasiswa Akuntansi. 1(4): 82-87.

PT Pefindo. www.pefindo.com.

Sari, Maylia Pramono. (2007) "Kemampuan Rasio Keuangan Sebagai Alat Untuk Memprediksi Peringkat Obligasi (PT Pefindo)”. Jurnal Bisnis dan Ekonomi (JBE). 14 (2): 172-182.

Sejati, Grace Putri. (2010) “Analisis Faktor Akuntansi dan Non Akuntansi dalam Memprediksi Peringkat Obligasi Perusahaan Manufaktur”. Bisnis \& Birokrasi. Jurnal Ilmu Administrasi dan Organisasi. 17 (1): 70-78.

Septyawanti, Hilda Indria. (2013) "Faktor-faktor yang Mempengaruhi Peringkat Obligasi Perusahaan”. Accounting Analysis Journal. Universitas Negeri Semarang. 2 (3): 276285.

Subramanyam, K. R. dan John J. Wild. (2008) Financial Statement Analysis. $10^{\text {th }}$ ed. New York: McGraw-Hill. 